\title{
Suppression of Fusarium moniliforme in Rice by Rice-Associated Antagonistic Bacteria
}

\author{
A. M. Rosales and T. W. Mew, Division of Entomology and Plant Pathology, International Rice Research Institute, \\ P.O. Box 933, Manila 1099, Philippines
}

\begin{abstract}
Rosales, A. M., and Mew, T. W. 1997. Suppression of Fusarium moniliforme in rice by riceassociated antagonistic bacteria. Plant Dis. 81:49-52.

The potential of antagonistic bacteria from paddy water, rhizosphere soils, sclerotia, and rice plants to control "bakanae" caused by Fusarium moniliforme was assessed. Experiments were conducted to determine the in vitro antibiosis and effect of bacteria on seed germination. Out of 441 isolates, 113 were inhibitory to mycelial growth of the pathogen. Bacterial strains were classified into three groups based on effect on seed germination: (i) those that promoted germination and enhanced seedling vigor; (ii) those that had no effect on germination; and (iii) those that were deleterious and inhibited germination. Bacterization of naturally infected seeds reduced bakanae incidence in seedbox and seedbed tests. In a seedbed experiment with IR 58 seeds soaked in suspensions of bacterial strains, bakanae incidence and disease control ranged from 0.9 to $6.8 \%$ and 71.7 to $96.3 \%$, respectively. From the 3 years of field trials, 10 strains reduced bakanae. Five strains consistently reduced bakanae, but the other five exhibited variable effects among trials. Specificity of suppression by antagonistic bacteria against different pathogenic isolates of $F$. moniliforme from various locations in the Philippines was observed.
\end{abstract}

"Bakanae" caused by Fusarium moniliforme Sheldon is a disease of rice first described in Japan, and now widely distributed in Asia. The typical symptom is the abnormal elongation of seedlings. The pathogen has a wide host range and is widespread throughout the world. The fungal pathogen is also known to cause stalk rot and leaf blight of corn, stalk rot of sorghum, endosepsis of fig (1), and crown rot of asparagus (2).

On rice, $F$. moniliforme induces seedling elongation, foot rot, seedling rot, grain sterility, and grain discoloration (11). The pathogen can be both seed-borne and soilborne. Generally, the seed-borne inoculum provides initial foci for secondary infection. Under favorable environmental conditions, infected plants in different foci have the capacity to produce numerous conidia that subsequently infect proximate healthy plants, which results in yield loss (11).

In recent years in Japan, raising rice seedlings in seedboxes for mechanical transplanting has created many seedling disease problems that were not considered important with open-field nursery for manual transplanting. Among the fungal diseases, bakanae is frequently encountered

Corresponding author: T. W. Mew, EPPD, IRRI, P.O. Box 933, Manila, Philippines; E-mail: T.MEW@cgnet.com

Accepted for publication 9 September 1996.

Publication no. D-1996-1101-04R

(C) 1997 The American Phytopathological Society and considered important (10). Even in open-field nurseries, one of the problems encountered by farmers in the control of bakanae disease is the difficulty in distinguishing infected seedlings from healthy plants, because there are no obvious symptoms of infected seedlings except the height or slight pale yellowing at the stage of transplanting (5). The fungus not only causes considerable damage on many plants, but also is parasitic on plants without producing visible symptoms (3). It can be isolated even from kernels that are healthy in appearance. Rice seedlings that grow from these infected seeds tended to display bakanae symptoms (12).

Currently, the most common management practice for bakanae is seed treatment with fungicides; however, resistance of the fungal pathogen to the fungicides has been reported (10). The objective of the present study was to determine if rice-associated microorganisms from paddy water, rhizosphere soils, and rice plants are antagonistic to $F$. moniliforme. A brief account of this work was previously reported (8).

\section{MATERIALS AND METHODS}

Sources and maintenance of antagonistic bacteria. Strains of antagonistic bacteria were obtained from the plant pathology culture collection at IRRI. These bacteria were tested against Rhizoctonia solani Kühn, the sheath blight pathogen, as previously reported (7). Bacteria were grown on King's medium B (KMB) (6) and nutrient agar (NA) for routine use, and these were lyophilized prior to storage at $-20^{\circ} \mathrm{C}$.
Detection of antagonistic activity in vitro. Evaluation of indigenous bacteria for antagonism against a virulent isolate of $F$. moniliforme (isolate F-24) was carried out in vitro. Four hundred forty-one bacterial strains collected from paddy water and rhizosphere soils of rice plants were tested by the dual-culture method. One milliliter of conidial suspension $(50,000$ conidia/ml) of the pathogen was added to each plate containing potato dextrose agar (potato, $200 \mathrm{~g}$; dextrose, $20 \mathrm{~g}$; agar, $17 \mathrm{~g}$; per liter). A loopful from 24-h-old culture of bacteria grown in KMB or NA slant was placed in four equidistant places in plates. Three replications were made for each strain. Inhibition zones were measured after incubation of the plates at $28^{\circ} \mathrm{C}$ for 24 to $48 \mathrm{~h}$.

A blotter method was used to evaluate the effect of bacteria on seed germination. Seeds of cv. IR42 were soaked in bacterial suspension $\left(10^{9} \mathrm{CFU} / \mathrm{ml}\right)$ for $24 \mathrm{~h}$. Twentyfive treated seeds were placed in each plate with moistened filter paper and incubated at $28^{\circ} \mathrm{C}$ with a 12 -h light/12-h dark cycle for 1 week. A total of 400 seeds were used for each strain. Seed germination, hypocotyl length, and radicle length were measured. Preliminary results of this experiment were reported earlier (8). Another method was also used: $200 \mathrm{~g}$ of seeds soaked in bacterial suspension $\left(10^{9} \mathrm{CFU} / \mathrm{ml}\right)$ was placed in plastic plates $(14 \mathrm{~cm}$ in diameter) with wet filter paper. These plates were then incubated at room temperature for 7 days.

Seedbed evaluation. Seeds of cv. IR58 were coated with bacteria as previously described (7) by soaking in bacterial suspension $\left(10^{9} \mathrm{CFU} / \mathrm{ml}\right)$.

A seedbed $(25 \times 1.5 \mathrm{~m})$ was prepared in naturally infested field soil. Strains that produced an inhibitory effect against $F$. moniliforme and $R$. solani were selected and screened for their effectiveness against bakanae. Ninety-five strains were used in the first year while 102 strains were used in the second and third years of the trial. These bacteria were isolated from various sources: paddy water (14 strains); infected plant in lowland field (7 strains); infected plant in upland field (4 strains); healthy plant in lowland (7 strains); healthy plant in upland (9 strains in 1986, 10 in 1988 and 1989); sclerotia of $R$. solani from lowland (16 strains); sclerotia of $R$. solani from upland (12 strains in 1986 and 13 in 1988 and 1989); rhizosphere soil of healthy plant (22 strains in 1986 and 27 in 1988 and 
1989); and rhizosphere soil of infected plant (4 strains). Two hundred fifty grams of IR58 seeds was soaked separately in each suspension for $12 \mathrm{~h}$ and sown in the seedbed. The experiment was laid out in a randomized complete block design with four replications in the first and second years and three replications in the third year. Disease incidence was observed 2 weeks after sowing. The performance of the strains in suppressing bakanae was determined for 3 years in the same seedbed. Data were grouped based on sources of bacteria, then analyzed with the IRRISTAT program developed by Biometrics at IRRI.

Efficacy of antagonistic bacteria against $\boldsymbol{F}$. moniliforme. Twenty isolates of $F$. moniliforme collected from different locations were used in this study. The pathogen was isolated from infected rice plants collected from Laguna (12 isolates), Leyte (1 isolate), Bicol (5 isolates), Nueva Ecija (1 isolate), and Cavite (1 isolate). All isolates were tested for pathogenicity of IR42 and IR58 in a greenhouse conditions.

Seventeen bacterial strains were individually tested for antagonism against 20 isolates of $F$. moniliforme. Procedures for detection of antagonistic activity in vitro as described in this paper were followed. Seedling tests were done in the greenhouse to determine the ability of 17 bacterial strains to control bakanae infection in IR58. Infected seeds of IR58 were obtained from plants artificially inoculated with $F$. moniliforme strain F-24. The inoculum of $F$. moniliforme was prepared with rice hull/rice grain substrate ( 3 parts rice hull/1 part rice grain in $200 \mathrm{ml}$ of water by volume). The mixture was packed in 500-ml culture bottles (400 g per bottle) and autoclaved at $121^{\circ} \mathrm{C}$ for $3 \mathrm{~h}$. The pathogen was transferred aseptically and incubated for 7 days at room temperature. Inoculum was added to soil in plastic containers. Infested soil was covered with plastic film and incubated for $48 \mathrm{~h}$. Two grams of infected seeds was soaked in $4 \mathrm{ml}$ of bacterial suspension for $24 \mathrm{~h}$, then planted in the soil previously infested with $F$. moniliforme. This experiment had three replications and was arranged in a randomized complete block design. Seedlings with bakanae symptoms were recorded 2 weeks after planting.

\section{RESULTS AND DISCUSSION}

One hundred thirteen strains were inhibitory to the mycelial growth of $F$. moniliforme. Some of the bacteria also inhibited conidial germination. They were also effective in reducing bakanae incidence in artificially infested soil in the greenhouse (14).

Results of the blotter and seed germination tests indicated that the effect of bacteria can be classified into three groups: (i) those that promoted seed germination and enhanced seedling vigor; (ii) those that had no effect on seed germination, compared
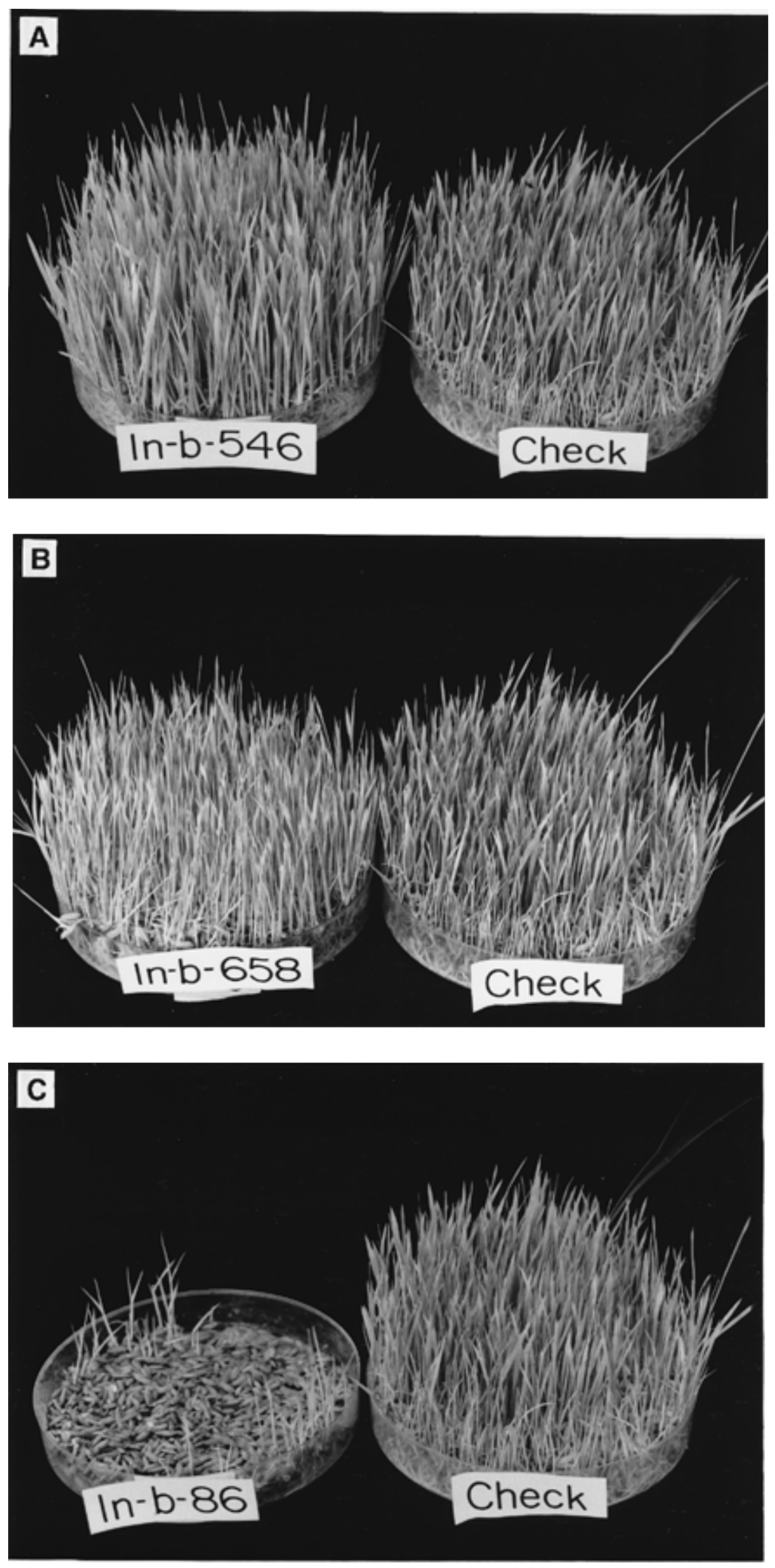

Fig. 1. Antagonistic bacteria effects on the germination of rice seedlings. (A) Promote seed germination and enhanced seedling vigor. (B) No effect on germination. (C) Deleterious effect on seed germination. 
with the untreated seeds; and (iii) those that were deleterious to seed germination, compared with the untreated seeds (Fig. 1).

Bakanae incidence in seedlings grown from bacteria-treated seeds in the seedbed was less, compared with the check. Bacteria were grouped based on the efficacy of the strains to suppress bakanae. Group 1: low bakanae incidence ( 0 to $14 \%$ in year 1 , 0 to $7 \%$ in years 2 and 3). Group 2: moderate low bakanae incidence (14 to $21 \%$ in year 1,7 to $14 \%$ in years 2 and 3). Group 3: moderate high bakanae incidence $(>22$ to $26 \%$ in year $1,>14 \%$ in years 2 and 3$)$. Group 4: high bakanae incidence $(>27 \%$ in year $1,>14 \%$ in years 2 and 3) (Table 1). Based on this grouping, 52, 81, and 50 strains were classified in group 1, whereas 22,13 and 46 strains were in group 2 , in years 1,2 , and 3 , respectively. Strains In-b521, In-b-442, In-b-520, and In-b-784 consistently reduced bakanae, whereas strains In-b-527 and In-b-715 were effective only in the first year of the trial (Fig. 2). Strains In-b-33 and In-b-714 were effective only in the second year.

Bakanae incidence was also reduced over time in the untreated plants from 1986 to 1989 . This could be due to contamination of the untreated plots with antagonists

Table 1. Strains of antagonistic bacteria suppressing bakanae in seedbed

\begin{tabular}{|c|c|c|c|c|c|c|c|c|c|c|c|c|}
\hline \multirow[b]{3}{*}{ Source $^{x}$} & \multicolumn{12}{|c|}{ Strains (no.) } \\
\hline & \multicolumn{3}{|c|}{ Group $1^{z}$} & \multicolumn{3}{|c|}{ Group 2} & \multicolumn{3}{|c|}{ Group 3} & \multicolumn{3}{|c|}{ Group 4} \\
\hline & $\mathbf{1}^{\mathrm{y}}$ & 2 & 3 & 1 & 2 & 3 & 1 & 2 & 3 & 1 & 2 & 3 \\
\hline 1 & 9 & 9 & 10 & 3 & 5 & 4 & 2 & 0 & 0 & 0 & 0 & 0 \\
\hline 2 & 4 & 7 & 3 & 3 & 0 & 4 & 0 & 0 & 0 & 0 & 0 & 0 \\
\hline 3 & 2 & 2 & 0 & 0 & 0 & 4 & 0 & 2 & 0 & 2 & 0 & 0 \\
\hline 4 & 3 & 4 & 5 & 2 & 0 & 2 & 0 & 3 & 0 & 2 & 0 & 0 \\
\hline 5 & 7 & 9 & 5 & 2 & 1 & 5 & 0 & 0 & 0 & 0 & 0 & 0 \\
\hline 6 & 8 & 16 & 10 & 4 & 0 & 6 & 3 & 0 & 0 & 1 & 0 & 0 \\
\hline 7 & 8 & 12 & 5 & 1 & 1 & 6 & 0 & 0 & 0 & 0 & 0 & 0 \\
\hline 8 & 10 & 18 & 11 & 6 & 6 & 12 & 0 & 3 & 0 & 6 & 0 & 0 \\
\hline 9 & 1 & 4 & 1 & 1 & 0 & 3 & 1 & 0 & 0 & 1 & 0 & 0 \\
\hline Total & 52 & 81 & 50 & 22 & 13 & 46 & 6 & 8 & 0 & 15 & 0 & 0 \\
\hline
\end{tabular}

${ }^{\mathrm{x}}$ Sources of bacteria: $1=$ paddy water; $2=$ sheath blight infected plant from lowland; $3=$ infected plant from upland; $4=$ healthy plant from lowland; $5=$ healthy plant from upland; $6=$ sclerotia from lowland; $7=$ sclerotia from upland; $8=$ rhizosphere soil of healthy plant; and $9=$ rhizosphere soil of infected plant.

${ }^{y}$ Number refers to year of trial.

${ }^{z}$ Grouping was based on bakanae incidence subjected to Duncan's multiple range test. Year 1: group 1,0 to $14 \%$; group 2, 14 to $21.8 \%$; group 3, 22 to $26 \%$; group 4, $\geq 27 \%$. Years 2 and 3: group 1, 0 to $7 \%$; group 2,7 to $14 \%$; group $3, \geq 14 \%$.

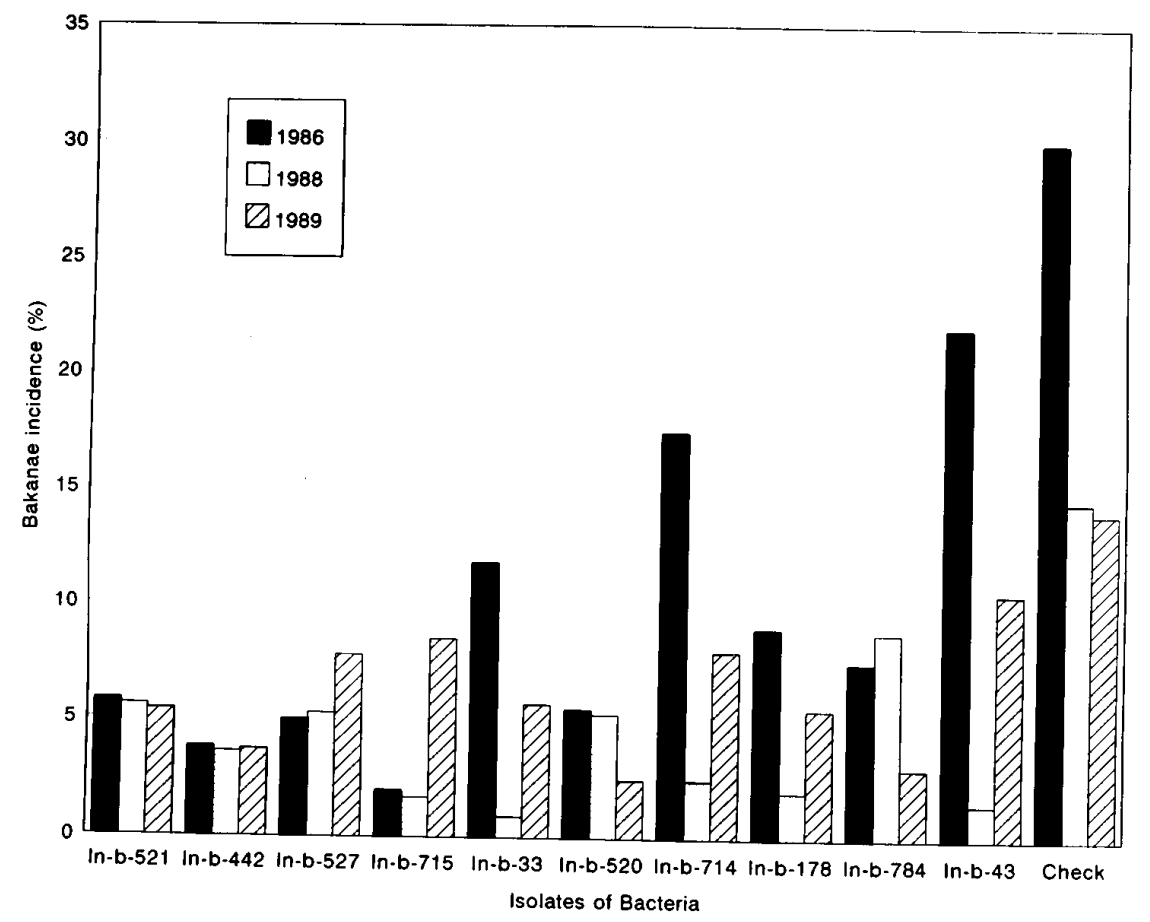

Fig. 2. Performance of 10 strains of antagonistic bacteria in suppressing bakanae in seedbed naturally infested with Fusarium moniliforme.

during land preparation and irrigation. It was also observed that seedlings grown from seeds treated with bacteria were healthier and more vigorous than those grown from untreated seeds (Fig. 3). Visual examination of the seedlings showed that the majority had brown discolorations in the roots and bases of the stem. These observations concurred with the findings of Ito and Kimura (4) that the pathogen became systemic and multiplied within the vascular tissues, particularly in large pitted vessels and lacunae of the xylem, thereby inducing brown lesions in roots and stems of seedlings grown in naturally infested soil.

In the present study, the effect of antagonists on bakanae could be attributed to other unknown mechanisms since the plants from treated seeds were healthier and greener than those from nontreated seeds. This could be due to suppression of initial inoculum in the seeds by seed soaking in bacterial suspension, since $F$. moniliforme is seed-borne. This could also be due to detoxification of fusaric acid, a phytotoxin produced by $F$. moniliforme, as shown by Toyoda et al. (15) while working on a mutant of $P$. solanacearum with a capacity to detoxify fusaric acid. It is possible that extracellular, heat-stable proteinases produced by rhizobacteria from the genus Pseudomonas could have a role in the inactivation of polysaccharide hydrolases of soilborne, pathogenic strains of Fusarium spp. (13). These mechanisms need to be investigated with bacteria associated with rice plants.

In an experiment to determine the interactions of 20 Fusarium isolates and 17 strains of antagonistic bacteria, results showed that three strains were effective against five isolates of Fusarium whereas

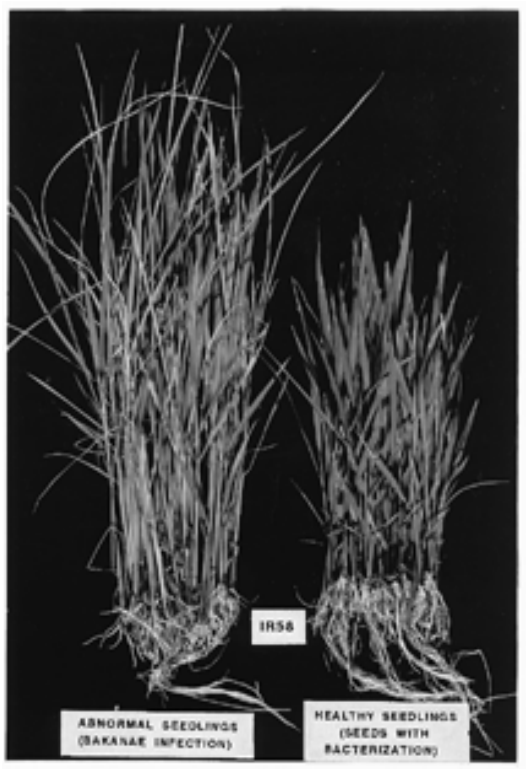

Fig. 3. Seedlings grown from bacteria-treated seeds were more healthy and had less bakanae infection than did untreated seedlings. 
Table 2. Bakanae incidence (\%) in relation to isolates of Fusarium and isolates of antagonistic bacteria applied as seed treatment in the greenhouse

\begin{tabular}{lccccc}
\hline & \multicolumn{5}{c}{ Fusarium isolates } \\
\cline { 2 - 5 } Bacteria isolates & $\begin{array}{c}\text { F-2 } \\
\text { (Cavite) }\end{array}$ & $\begin{array}{c}\text { F-13 } \\
\text { (Leyte) }\end{array}$ & $\begin{array}{c}\text { F-27 } \\
\text { (Nueva Ecija) }\end{array}$ & $\begin{array}{c}\text { F-22 } \\
\text { (Laguna) }\end{array}$ & $\begin{array}{c}\text { F-19 } \\
\text { (Bicol) }\end{array}$ \\
\hline In-b-521 & $1.7 \mathrm{a}^{\mathrm{z}}$ & $4.0 \mathrm{a}$ & $12.7 \mathrm{ab}$ & $5.0 \mathrm{ab}$ & $2.7 \mathrm{a}$ \\
In-b-442 & $3.0 \mathrm{a}$ & $4.7 \mathrm{a}$ & $8.3 \mathrm{a}$ & $3.7 \mathrm{a}$ & $3.0 \mathrm{a}$ \\
In-b-527 & $4.7 \mathrm{a}$ & $6.3 \mathrm{a}$ & $8.7 \mathrm{a}$ & $1.3 \mathrm{a}$ & $2.0 \mathrm{a}$ \\
In-b-715 & $18.0 \mathrm{~b}$ & $18.0 \mathrm{abc}$ & $29.7 \mathrm{c}$ & $16.7 \mathrm{bcd}$ & $18.0 \mathrm{~b}$ \\
In-b-33 & $24.3 \mathrm{bc}$ & $32.0 \mathrm{cde}$ & $64.0 \mathrm{fg}$ & $51.3 \mathrm{fgh}$ & $50.0 \mathrm{~d}$ \\
In-b-520 & $25.3 \mathrm{bc}$ & $25.0 \mathrm{bcde}$ & $36.7 \mathrm{~cd}$ & $19.3 \mathrm{~cd}$ & $28.0 \mathrm{bc}$ \\
In-b-714 & $33.7 \mathrm{cde}$ & $19.7 \mathrm{abcd}$ & $24.3 \mathrm{bc}$ & $10.0 \mathrm{abc}$ & $23.3 \mathrm{~b}$ \\
In-b-178 & $31.7 \mathrm{cde}$ & $35.3 \mathrm{de}$ & $60.7 \mathrm{efg}$ & $52.3 \mathrm{~h}$ & $49.3 \mathrm{de}$ \\
In-b-837 & $27.0 \mathrm{bcd}$ & $14.7 \mathrm{ab}$ & $30.0 \mathrm{c}$ & $26.7 \mathrm{de}$ & $22.7 \mathrm{~b}$ \\
Check & $30.7 \mathrm{~cd}$ & $31.7 \mathrm{cde}$ & $58.7 \mathrm{ef}$ & $40.0 \mathrm{fgh}$ & $26.7 \mathrm{bc}$ \\
\hline
\end{tabular}

${ }^{\mathrm{z}}$ Means followed by a common letter are not significantly different at the $5 \%$ level by Duncan's multiple range test.

Table 3. Bakanae incidence (\%) in IR58 rice infected with Fusarium isolates from Laguna and bacterized with antagonistic bacteria isolated from rice plants in Nueva Ecija

\begin{tabular}{lccr}
\hline \multirow{2}{*}{$\begin{array}{l}\text { Fusarium } \\
\text { isolates }\end{array}$} & \multicolumn{3}{c}{ Bacterial isolates $^{\mathrm{z}}$} \\
\cline { 2 - 4 } & In-b-714 & In-b-715 & Check \\
\hline F-4 & 28.00 & 29.67 & 22.67 \\
F-5 & 3.00 & 6.00 & 12.00 \\
F-11 & 2.67 & 9.67 & 4.00 \\
F-12 & 38.67 & 25.00 & 24.33 \\
F-14 & 23.33 & 23.00 & 32.00 \\
F-15 & 7.00 & 4.67 & 4.67 \\
F-17 & 14.00 & 17.00 & 13.67 \\
F-20 & 6.67 & 5.00 & 7.00 \\
F-22 & $20.00 * *$ & $16.67 * *$ & 40.00 \\
F-23 & 14.00 & $5.67 *$ & 16.67 \\
F-24 & 16.33 & 13.00 & 10.00 \\
F-25 & 8.67 & 4.00 & 9.00 \\
\hline
\end{tabular}

${ }^{\mathrm{z}}$ Values followed by an asterisk are significantly different from the control based upon least significant difference in which $*$ and $* *$ are significant at $P<0.05$ or 0.01 , respectively.

the others were isolate-specific (Table 2). When the two strains of bacteria from Nueva Ecija, In-b-714 and In-b-715, were tested against Fusarium isolates from different locations, they were effective only against Fusarium isolates from Nueva Ecija, Laguna, and Leyte. These two strains were effective against two out of 12 Fusarium isolates from Laguna (Table 3). This indicates specificity of suppression by antagonistic bacteria against different pathogenic isolates of $F$. moniliforme in the Philippines. Antagonist $\times$ pathogen interactions are of importance to plant pathologists seeking to identify a stable antagonist for biological control of plant diseases. Comparison of antagonists against a series of plant-pathogenic isolates reveals differences in the relative rankings. If stability of antagonism, i.e., the ability to show a minimum of interaction with changes in pathogen isolates, is a genetic characteristic, the identification of stable antagonist is of obvious value to plant pathologists (16). A study conducted by Utkhede and Rahe (16) to identify stable antagonists against Sclerotium cepivorum showed that significant differences in antagonism were detected among the isolates of bacteria. The order of antagonists, ranked according to antagonism and ability to control onion white rot, depended on the isolate of S. cepivorum tested. This implied that, in future studies, screening of isolates with broad-spectrum activity should be considered. Also, specificity of suppression may explain why a given isolate does not perform effectively against the pathogen in different locations. These hypotheses merit further investigation.

Differences in virulence of pathogenic isolates of $F$. moniliforme were observed in this study. As shown in Table 2, bakanae incidence differed among the untreated seeds of the five isolates tested; e.g., F-27 from Nueva Ecija is more virulent than other isolates, and F-19 from Bicol is the least virulent. A similar trend was observed Table 3. Seeds without bacterial application but sown in Fusarium-infested soil showed a wide range of incidence, indicating that variation in virulence of the pathogen isolate exists. The existence of race groups of $F$. moniliforme in the Philippines was reported by Nuque et al. (9). With the use of the reactions of eight differentials, 56 isolates of $F$. moniliforme were classified into nine race groups. with 12 isolates from Laguna, as shown in
Whether the bacterial strains used in this study exhibit race-specificity warrants further investigation.

\section{LITERATURE CITED}

1. Booth, C. 1971. The Genus Fusarium. Commonw. Mycol. Inst., Kew, England.

2. Endo, R. M. and Burkholder, E. C.. 1971. The association of Fusarium moniliforme with the crown rot complex of asparagus. (Abstr.) Phytopathology 6:891.

3. Hsieh, W. H., Smith, S. N., and Snyder, W. C. 1977. Mating groups in Fusarium moniliforme. Phytopathology 67:1041-1043.

4. Ito, S., and Kimura, J. 1931. Studies on the bakanae disease of the rice plant. (In Japanese, with English summary.) Rep. Hokkaido Agric. Exp. Stn. 27:1-95 + 5 .

5. Kim, C. K. 1981. Ecological studies of bakanae disease of rice caused by Gibberella fujikoroi. Korean J. Plant Prot. 20:146-151.

6. King, E. O., Ward, W. K., and Raney, D. E. 1954. Two simple media for the demonstration of pyocyanin and fluorescein. J. Lab. Clin. Med. 44:301-307.

7. Mew, T. W., and Rosales, A. M. 1986. Bacterization of rice plants for control of sheath blight caused by Rhizoctonia solani. Phytopathology 76:1260-1264

8. Mew, T. W., and Rosales, A. M. 1992. Control of Rhizoctonia sheath blight and other diseases of rice by seed bacterization. Pages 113 123 in: Biological Control of Plant Diseases. E. S. Tjamos, G. C. Papavizas, and R. J. Cook, eds. Plenum Press, New York.

9. Nuque, F. L., Vergel de Dios, T., and Crill, J. P. 1981. Pathogenic races of Fusarium moniliforme in the Philippines. Philipp. Phytopathol. 17:9.

10. Ogawa, K. 1988. Damage by "bakanae" disease and its chemical control. Jpn. Pestic. Inf. 52:13-15.

11. Ou, S. H. 1985. Rice Diseases. 2nd ed. Commonwealth Mycol. Inst., Kew, England.

12. Padwick, G. W. 1950. Manual of Rice Diseases. Commonwealth Mycol. Inst., Kew, England. pp. 74-84

13. Pietr, S. J. 1990. Inhibition of culture filtrate toxicity and hydrolase activity of phytopathogenic Fusarium spp. by plant-growth promoting Pseudomonas fluorescens. Pages 147 151 in: Plant Growth-promoting Rhizobacteria, Progress and Prospects. C. Keel, B. Koller, and G. Defago, eds. Int. Org. Biol. Integr. Contr. Noxious Anim. Plants, Interlaken, Switzerland.

14. Rosales, A. M., Nuque, F. L., and Mew, T. W. 1986. Biological control of bakanae disease of rice with antagonistic bacteria. Philipp. Phytopathol. 22:29-35.

15. Toyoda, H., Hashimoto, H., Utsumi, R., Kobayashi, H., and Ouchi, S. 1988. Detoxification of fusaric acid by a fusaric acid-resistant mutant of Pseudomonas solanacearum and its application to biological control of Fusarium wilt of tomato. Phytopathology 78:13071311

16. Utkhede, R. S., and Rahe, J. E. 1983. Interactions of antagonist and pathogen in biological control of onion white rot. Phytopathology 73:890-893. 